\title{
Gift of Blue Carbon
}

\author{
Nabonita Pal ${ }^{1}$, Abhijit Mitra ${ }^{2 *}$ and Sufia Zaman ${ }^{1}$ \\ ${ }^{1}$ Department of Oceanography, India
}

${ }^{2}$ Department of Marine Science, India

*Corresponding author: Abhijit Mitra, Department of Marine Science, India

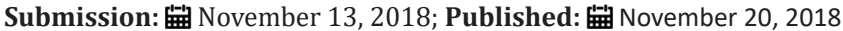

\section{Mini Review}

Many of the researchers prefer the term 'ecosystem services' for highlighting the benefits from various flora and fauna thriving in the ecosystems of varied nature. However, the term 'service' is not very pertinent in this context, as service means a sort of 'give and take' interaction. In case of flora and fauna present in the planet earth, human being is extracting wide spectrum of benefits from these organisms but does not pay any honorarium against the services provided by the organisms. Starting from timber to medicine- all are the gifts of flora and fauna. The gifts provided by blue carbon are very important for the survival and betterment of human society [1-5]. The term 'blue carbon' encompasses coastal vegetation like mangroves, seagrasses, seaweeds, salt marsh grasses etc. They not only protect the coastal zone from erosion, but also act as major line of defence against storms, wave actions, tidal surges etc. The mangroves provide timber, honey, wax, fuel wood etc. The mangroves seagrasses and salt marsh bed act as the nursery and breeding ground of several species of fin fishes and shell fishes. The medicinal properties of mangroves have immense value in the modern pharmaceutical industries. It has also been documented by researchers that application of PGPR (Plant Growth Promoting Rhizo-bacteria) isolated from halophytes in agricultural field act as a substitute of chemical fertilizer and promotes the growth of agricultural crops. In recent period, a new feather has been added in the service spectrum of coastal vegetation which is directly connected with the phenomenon of climate change. The carbon sequestered by the halophytes is an eco-friendly lane to mitigate the rise of carbon dioxide at the local level. A case study conducted in Indian Sundarbans in the lower at the apex of Bay of Bengal exhibited the rise of carbon dioxide since, the last three decades in all the three seasons (Figure 1). This rise has several adverse impacts like rise of temperature, acidification and proliferation of diseases and loss of biodiversity. Such rise can be effectively controlled by the members of blue carbon community through natural sequestration without any investment. Considering all these benefits provided by the coastal vegetation without getting any return from the human society, question arises whether the term 'ecosystem service' is appropriate or should be replaced by 'societal gifts'.

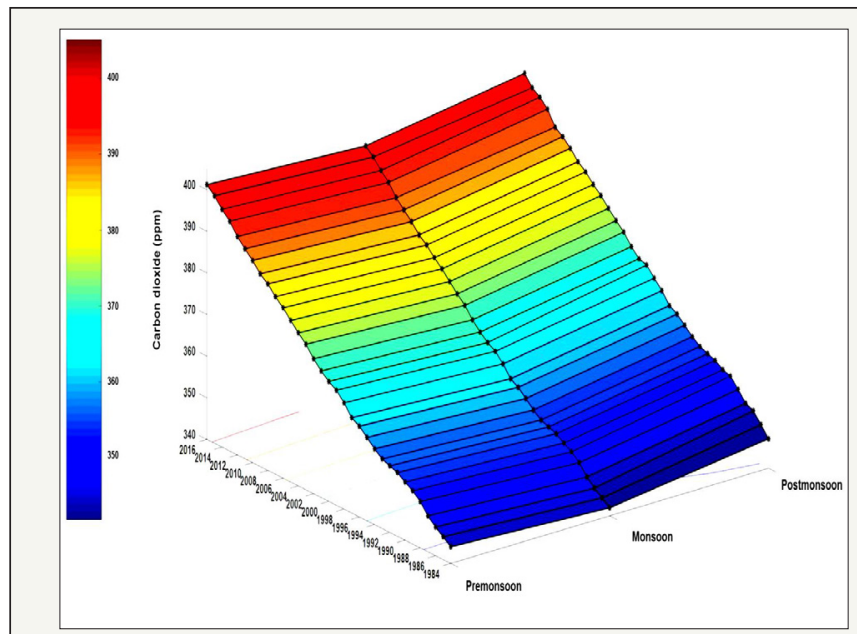

Figure 1: Trend of atmospheric carbon dioxide at Sagar Island in Indian Sunadrabans [5].

\section{References}

1. Mitra A (2013) Sensitivity of mangrove ecosystem to changing climate. Springer, Germany, p. 323.

2. Mitra A, Zaman S (2014) Carbon sequestration by coastal floral community. The Energy and Resources Institute (TERI) TERI Press, India.

3. Mitra A, Zaman S (2015) Blue carbon reservoir of the blue planet. Springer, Germany, DOI: 10.1007/978- 81-322-2107-4.

4. Mitra A, Zaman S (2016) Basics of marine and estuarine ecology. Springer, Germany, ISBN 978-81- 322-2705-2.

5. Agarwal SK, Fazli P, Zaman S, Mitra A (2018) Near surface air temperature and carbon dioxide in Indian sundarbans: A time series analysis. Parana Journal of Science and Education 4(1): 10-15. 
Creative Commons Attribution 4.0 International License

For possible submissions Click Here

Submit Article
Examines in Marine Biology \& Oceanography

\section{Benefits of Publishing with us}

- High-level peer review and editorial services

- Freely accessible online immediately upon publication

- Authors retain the copyright to their work

- Licensing it under a Creative Commons license

- Visibility through different online platforms 